\title{
Sujeitos, convenções e diferenças em narrativas: sobre Carla, Bárbara e Renata
}

\author{
Bruno Cesar Barbosa
}

\begin{abstract}
resumo Neste artigo irei discutir, a partir de narrativas de história de vida, os usos de categorias relacionadas a identidades sexuais e de gênero, sobretudo as categorias travesti e transexual, e como se elaboram as diferenças entre estas categorias. Argumento que embora as convençóes do discurso médico sejam referências centrais para a definição de corpos, subjetividades e identidades das pessoas pesquisadas, é possível observar uma variedade de reelaboraçóes e deslocamentos de sentidos na construção das trajetórias biográficas que têm relação direta com as situaçóes sociais presentes e os variados contextos de interlocução.
\end{abstract}

palavras-chave Travestis. Transexuais. Diferenças. Gênero. Sexualidade.

"Quem é você?", disse a Lagarta. Não era um começo de conversa muito estimulante. Alice respondeu um pouco tímida: "Eu... eu... no momento não sei, minha senhora... pelo menos sei quem eu era quando me levantei hoje de manhá, mas acho que devo ter mudado várias vezes desde então (Carroll, 2007 [1865], p.60).

\section{Introdução}

Este artigo traz resultados de minha pesquisa de mestrado (Barbosa, 2010), na qual investiguei os usos de categorias referidas como identidades sexuais e de gênero a partir de pesquisa de campo no cotidiano de um serviço direcionado para LGBT, o Centro de Referência em Diversidade (CRD), localizado em São Paulo, Brasil. Neste serviço tomei como lócus privilegiado de análise as Terças Trans ${ }^{1}$, que são reuniōes quinzenais direcionadas para pessoas trans $^{2}$ organizadas pela Secretaria de Travestis, Transexuais e Transgêneros da Associaçáo da Parada do Orgulho LGBT de São Paulo.

As Terças Trans, em sua maioria, são compostas por pessoas que se autoidentificam como transexuais e trans. A frequência é altamente variada, sendo que durante as observaçóes desta pesquisa, realizadas durante 2008 e 2009, regularmente participam cerca de dez pessoas, das quais nenhuma trabalha na prostituição. Grande parte delas utiliza o termo transexual como autodefinição. Somente uma pessoa que participava do grupo identificava-se como travesti. As idades das participantes variavam de 20 a 60 anos, tendo uma maior prevalência de maiores de 35 anos.

Nas observaçóes de campo das Terças Trans e do cotidiano das atividades do CRD pude perceber uma variedade de usos de categorias e convençóes por estas pessoas, desde categorias que elas consideram mais convencionalizadas, como transexual e travesti, até categorias como transex, trans, mulheres que vivem a transexualidade, travestilidade, além de categorias ligadas à homossexualidade, como homossexual, gay, bicha, viado, e a oposição entre passivo e ativo. Pude perceber também que mesmo os significados considerados mais convencionais em 
48 Bruno Cesar Barbosa

relação às categorias travesti e transexual e suas diferenças eram foco de discussão e controvérsia entre as participantes.

Essa proliferação de categorias de classificação me chamou atenção para as convençóes que definiam essas categorias, além das transformaçóes produzidas nesse processo de agenciamento de convençóes. Deste modo, a questáo central que elegi na análise das interaçóes e entrevistas foi como as diferentes pessoas observadas utilizavam categorias relacionadas a identidades sexuais e de gênero e como acionavam diversas convenções nesse processo, elaborando sentidos e diferenças entre essas categorias.

Para lidar com essas indagaçóes em torno da pragmática dos sistemas classificatórios busquei inspiração em uma abordagem que me permitisse focalizar esses usos e práticas (Herzfeld, 2005). Deste modo, enfatizei a importância da "poética social" 3 para se entender qualquer processo de simbolização, pois significados nunca estão assegurados na prática social. Busquei compreender como as convençóes emergem nas práticas sociais dos próprios sujeitos e como são articuladas com outras convençôes, produzindo novas convençôes e inovaçôes (Wagner, 1981).

Investi na análise de interaçôes nas situaçóes das reuniôes e em narrativas de história de vida das pessoas que se reuniam nas Terças Trans. Neste artigo, irei me debruçar nas narrativas, enfocando os usos de categorias e convençôes agenciadas e articuladas como forma de produção de sujeitos e diferenças.

\section{Narrativas de história de vida}

Estudar histórias de vida nos permite olhar para a diversidade de formas com que os sujeitos se utilizam de convençóes para produzir sentidos sobre si e suas diferenças. Brah (2006) sinaliza que a investigaçáo acerca da subjetividade pode evidenciar como um significado atribuído a um evento varia enormemente de um sujeito para outro. Isso não significa retomar a noção de um sujeito livre e racional, já que as pessoas percebem ou concebem os eventos de acordo com a maneira como "elas" são culturalmente construídas. A agência emerge das próprias relaçóes, de modo que a própria capacidade de agir depende dessas relaçóes que constituem o sujeito, dos repertórios políticos e culturais disponíveis. Isto não significa que não exista mudança, pois se a prática é produtiva de poder, como na proposta foucaultiana de entender o discurso como prática, então é por meio desta mesma prática que deslocamentos e transformaçōes se fazem possíveis.

Esta ênfase nos aspectos "micro" das relaçôes sociais nos permite compreender a dinâmica de poder da diferenciação social em seus aspectos mais capilarizados. Brah (2006) propõe não privilegiar um nível micro ou macro de análise, mas entender "como articular discursos e práticas inscreve relaçóes sociais, posiçôes de sujeito e subjetividades" (Brah, 2006, p.359). O conceito de articulação, assim como em McClintock (1995), remete à prática. De fato, quando o foco recai sobre esta prática e sobre o próprio processo de significação, uma polarização entre níveis micro e macro torna-se infundada, pois tais dimensões são inerentes às inscrições que ela cita, aos processos de agenciamento de convenções.

No entanto, se enfatizei aqui que irei estudar histórias de vida, torna-se necessário discutir o que entendo por "histórias de vida". Como argumenta Bourdieu (1996), falar de "história de vida” é pressupor que a vida é uma história, isto é, "um conjunto de acontecimentos de uma existência individual concebida como uma história e o relato dessa história" (Op. cit., p.183). Segundo o autor, tal noção de história de vida é justamente o que diz o senso comum, que entende a vida como um caminho, uma estrada. Deste modo, tomar esta noção de história de vida de Bourdieu é abraçar uma filo- 
sofia do indivíduo e um tipo de entendimento da história como sucessão de acontecimentos.

Como apontam Brah (2006) e Butler (2003), a identidade emerge de relaçóes práticas, ela é o processo no qual uma "multiplicidade relacional em constante mudança” (Brah, 2006, p. 371) se enuncia como coerência e estabilidade. Tais práticas de produção do eu se evidenciam no relato autobiográfico, em que se pretende produzir um sentido, uma coerência entre os acontecimentos vivenciados pela pessoa, isto é, a filosofia do indivíduo e seu consequente entendimento da história. Assim, mesmo que os acontecimentos não tenham se desenrolado sempre em sua estrita sucessão cronológica, os relatos autobiográficos tendem ou pretendem organizar-se em sequências ordenadas segundo relaçôes inteligíveis. Nas palavras de Bourdieu:

Sem dúvida, cabe supor que o relato autobiográfico se baseia sempre, ou pelo menos em parte, na preocupação de dar sentido, de tornar razoável, de extrair uma lógica ao mesmo tempo retrospectiva e prospectiva, uma consistência e uma constância, estabelecendo relações inteligíveis, como a do efeito à causa eficiente ou final, entre os estados sucessivos assim constituídos em etapas de um desenvolvimento necessário. (Bourdieu, 1996, p.184)

Segundo Bourdieu (1996), nos relatos autobiográficos existe uma propensão dos sujeitos a se tornarem ideólogos de sua própria vida, selecionando, em função de uma intenção global entendida como causa e localizada no próprio sujeito, certos agenciamentos significativos e estabelecendo entre eles conexóes para lhes dar coerência. As experiências múltiplas vivenciadas são simbolizadas, assim, em tais relatos como frutos desta intenção global, que se torna o sujeito. Bourdieu destaca ainda como tal preocupação em dar sentido é algo que conta com a cumplicidade natural do biógrafo, que, por seu objetivo como um profissional da interpretação, só pode ser levado a aceitar essa criação artificial de sentido.

Penso que esta discussão de Bourdieu se aproxima do conceito de performatividade em Butler (2003), no qual a autora sinaliza para o processo pelo qual o sujeito se torna a causa das ações, o autor das experiências. Assim, poderíamos entender esta "criação artificial de sentido" como performativa, isto é, como uma das práticas produtoras e pelas quais emerge o "eu”. É um efeito retórico que produz o sujeito como causa de suas açôes e apaga as contingências desta construção. Bourdieu (1996) aponta que o mundo social dispóe de todo tipo de instituiçõos de totalização e de unificação do eu. O relato autobiográfico é uma destas instituições; são práticas discursivas de unificação do eu. Tais relaçôes produzem um sujeito unitário, coerente e coeso. No entanto, se há esta tendência do relato autobiográfico à coerência, tais narrativas também evidenciam uma série de incoerências e contradiçôes produzidas neste processo.

Desta forma, o objetivo do estudo de histórias de vida não está em recriar uma história biográfica. Como argumenta Kofes (1994), a partir do referencial de Bourdieu (1996), poderíamos falar de "estórias de vida" e "narrativas", em vez de histórias de vida, pois não nos interessa sabermos dos fatos como aconteceram, mas sim como acontecimentos são narrados e produzidos a partir das contingências atuais. Os sujeitos organizam seus relatos a partir das situaçóes presentes e são estas situaçôes, e a forma como o sujeito se posiciona em seu presente, que permitem criar essas totalidades do eu. Assim, acontecimentos passados podem ser narrados e produzidos de formas diferentes a partir de contingências diferenciais.

Para a discussão neste artigo irei trazer as narrativas de três frequentadoras das Terças Trans: Carla, Bárbara e Renata. Carla nasceu em São 
Paulo, tinha 54 anos no momento da entrevista, autoclassifica-se como branca, cursou até o primeiro ano do ensino médio e, de acordo com seu relato, tem origem em uma família de classe média do Bairro do Bosque da Saúde, na Zona Sul. Perguntada acerca de definiçôes em termos de classe, ela relatou ser de classe média. Ela tem acesso a bibliografias médicas, psicológicas e das ciências sociais que tenham como tema sexualidade e gênero e se interessa por elas. Já escreveu um livro autobiográfico e foi fonte de inspiração para um documentário sobre sua vida. Trabalha como performer desde os anos 1970. Relata nunca ter trabalhado na prostituição, nem mesmo quando esteve na Europa, onde, conforme conta, trabalhou em casas de show.

Bárbara, por sua vez, nasceu em uma cidade pequena do interior de Minas Gerais e tinha 59 anos no momento da entrevista. Perguntada acerca da autodefinição em termos de cor/raça, ela apontou ser morena cor de jambo, pois disse que tem uma cor que sempre parece que está bronzeada. Antes de vir para São Paulo, morou no Rio de Janeiro. Nos dois lugares, trabalhou na prostituição. Segundo seu relato, ela trabalhou de "manequim" em São Paulo para um estilista do final dos anos 1960 e recorrentemente sinaliza sua preocupaçáo com assuntos de moda e "beleza". Ela tem conhecimento acerca do trabalho de vários estilistas e se preocupa bastante com o que veste. Perguntada sobre por que parou de trabalhar com moda, disse que não recebia o salário como devia e teve, com isso, que ir trabalhar na prostituição. Nos anos 1980 se envolveu com os trabalhos de prevenção e tratamento às DST e Aids. Quando perguntei sua definição em termos de classe, ela disse: "a gente é marginal, né, vive sempre à margem, com essas pessoas da marginalidade como bandidos, traficantes, cafetão, tudo isso que é ilegal".

Já Renata autodenomina-se branca e, em termos de classe social, de classe média ou proveniente da pequena burguesia. Tinha 44 anos no momento da entrevista e é formada em letras, deu aulas de português e agora se encontra aposentada. Começou a se tornar travesti ou, em suas palavras, assumir [sua] travestilidade depois dos 40 anos. Até então se considerava homem heterossexual. Foi casada e teve um filho. Assim como Carla, Renata aponta uma intensa interlocução com literaturas científicas acerca de sexualidade e gênero. Ela sinaliza em seus relatos a importância dos trabalhos das ciências sociais e dos grupos de militância, que mostraram para ela que ser travesti não é uma experiência patológica, podendo ser fonte de orgulho. Até então, seu contato havia se dado com a literatura das ciências médicas e psicológicas. Achava que tinha um fetiche e já teve muitas dúvidas sobre os significados de seus desejos e práticas. Porém, atualmente sente orgulho de ser travesti e acha que sempre o foi, sendo que o preconceito a levou a não expressar [sua] travestilidade.

$\mathrm{Na}$ análise das narrativas biográficas estarei atento à forma como essas três pessoas organizam suas narrativas e aos contextos e situaçóes de usos pelos quais categorias ligadas a identidades sexuais e de gênero emergem e produzem identidades e diferenças pela articulação de uma série de convenções.

\section{"A prova física da diversidade": narrativa de Carla}

Quando pedi a Carla para se apresentar, ela disse:

Sou Carla, tenho 54 anos, sou paulistana, sou performer, né? Cantora, compositora, atriz, também sou escritora e ativista das causas sociais dos direitos humanos GLBT e em especial travestis, transexuais e intersexos.

É possível perceber que em uma frase de apresentação, na qual Carla é solicitada a escolher alguns atributos, ela toma como referência 
SUJEITOS, CONVENÇÕES E DIFERENÇAS EM NARRATIVAS $\mid$ II

a performer, ou o que ela chama de artista travesti, profissão com que trabalha desde os anos 1970. Neste contexto de apresentação, o fato de dizer-se performer também permite não se identificar como transexual ou travesti. Carla relata que já se identificou de várias formas durante sua vida, em suas palavras:

Eu cresci pensando que era homossexual, depois surgiu a discussão sobre travesti/transexual. Então, o que eu sou? Eu sou travesti, aí eu virei travesti nos anos 70. Sou travesti. Aí, nos anos 80 , eu sou transexual e até há pouco tempo eu achava que eu era transexual, apesar de não querer me operar. Mas, essa coisa do andrógino nunca me abandonou, eu sempre tive certeza de ser dois em um, tanto que assim quando eu comecei a frequentar a militância, aqui na Parada (referência à Associação da Parada do Orgulho LGBT de São Paulo), coisa de dez/onze anos atrás, quando começou a Parada, eu falava assim: eu quero a ambiguidade como identidade, porque eu náo quero ser homem e náo quero ser mulher, eu sou os dois, eu sou homem e sou mulher. Portanto, é ambiguidade, dualidade, é isso que eu quero como identidade.

Nota-se em sua fala uma interlocução com um vocabulário que vemos em muitos estudos sobre gênero e sexualidade, notadamente uma visão da identidade como ambiguidade e dualidade. Segundo conta Carla, as "leituras", "discussóes" e "informaçôes" não somente a "informaram”, mas também mudaram a forma como ela entendia suas próprias vivências. Deste modo, a narrativa adquire diferentes temporalidades, na medida em que o acesso às novas discussóes e informaçóes passa a rearticular suas vivências passadas.

A narrativa de Carla é organizada em torno da sua descoberta de ser intersexo - um acontecimento recente, que ela privilegia para caracterizar sua situação presente. Essa descoberta rearticula uma série de eventos de sua vida, e é nesse sentido que ela relata que essa coisa do andrógino nunca me abandonou. A narrativa desta descoberta é feita pela montagem de uma série de eventos que confirmam essa nova certeza de ser intersexo. A pergunta que deu início à narrativa da descoberta visava a explorar quando ela começou a se sentir diferente de outras pessoas e em que consistia essa diferença. Em um primeiro momento, essa diferença seria o fato de ser um menino que gosta de coisas de menina, expressa por eventos de discriminação na escola e com colegas. Segundo Carla, estes eventos fizeram com que seus pais a levassem a um psiquiatra. Em suas palavras:

Carla: Com onze anos, me levaram ao psiquiatra, muito inteligente e moderno pra época já. Eu tive sorte, e ele falou que tinham que me aceitar, do jeito que eu era. Depois ele pediu para eu tirar a roupa para fazer o exame, olhou o meu corpo, e ele receitou injeções de hormônio masculino, porque disse que eu tinha deficiência hormonal. Naquela época, eu não entendia o que era, e só fui descobrir o que era agora em 2004. Em 2004 eu descobri que nasci intersexo. Você sabe o que é?

Bruno: Se você quiser explicar, falar sobre isso... Carla: Intersexo é a pessoa que nasce com os dois, com as duas características, ou nasce com a genitália indefinida, e a minha era indefinida. Então os médicos, isso foi uma tia que me contou tudo em 2004, depois que meu pai e minha mãe faleceram, eles morreram com este segredo, e ela me contou que o médico queria castrar meu testículo para que eu crescesse como menina quando eu nasci. Com seis anos me levaram para fazer uma cirurgia de hérnia, que hérnia que nada que hoje eu descobri que naquele dia tiraram meu ovário, eu nasci com um ovário. E eu só fui entender isso agora, porque daí eu comecei a estudar, na internet e saber. Eu tinha visto um documentário uma vez, eu pensava que era uma coisa extraordinária, e depois eu 
$52 \mid$ Bruno Cesar Barbosa

descobri que não era uma coisa tâo rara assim. [...] Aí em 1999, eu fui num médico, num endócrino. Em 1999 eu tive um problema nessa região (apontando o abdômen) e o médico me receitou um exame de ultrassom. Aí, ele chama a enfermeira e, de repente, ele grita assim: "Ah! Olha o útero dela aqui". Eu achei engraçado, comecei a rir, e falei: "Ai, e travesti tem útero?" (risos). Mas aí eu olhei para a cara deles e eles não estavam rindo, eles estavam meio assim pasmos, e eu esqueci, pensei que era brincadeira. [...] Aí, ano passado eu fiz três meses de análise com uma psicóloga e teve um dia que ela me falou e eu nunca tinha falado de intersexo, e ela me falou que eu não me classificava nem como travesti, nem como transexual. Ela falou pra mim: "você já fez algum exame pra ver se você tem útero?". Aí, eu falei: "não”. E aí, me lembrei do negócio que aconteceu em 1999. Aí, ela falou que eu falava uma série de coisas, e sentia, de pessoas que têm útero. Aí que eu fui vasculhar mais ainda. Na minha vivência isso mudou, no sentido assim, eu sempre pensei, puxa vida, no começo eu achava que eu era homossexual, um homossexual efeminado que queria ser mulher.

Esta descoberta física de ser intersexo a faz olhar suas vivências passadas e ver uma androginia que sempre esteve lá. Essa operação evoca uma valorização de um estilo de interpretação que, seguindo Crapanzano (2002), poderíamos considerar como um tipo de "literalismo", baseado no corpo. O "texto fundamental" do literalismo de Carla é o ultrassom, que a permite fazer uma relação inequívoca entre palavra e coisa. O ultrassom marca uma "verdade absoluta”, onde não há espaços para discussão. A relação entre tal estilo e o conhecimento biomédico é evidente. Em sua narrativa, é possível perceber uma tensão com o saber médico: de um lado, um enfrentamento diante de um saber de "controle" do corpo, e de outro lado, uma aproximação pelo status dado ao saber médico como científico e verdade absoluta, expresso por sua valorização de um estilo de interpretação literalista. No entanto, percebemos que esta descoberta não a faz parar de utilizar outras categorias de classificação como, por exemplo, quando ela responde ao médico, em tom irônico: $e$ travesti tem útero? Existe uma dimensão retórica em seu argumento, pois o fato de ser intersexo parece possibilitar "ser" muitas outras coisas.

O fato de sua narrativa começar com o evento da sua ida ao psiquiatra com onze anos não é por acaso, pois a deficiência hormonal diagnosticada pelo médico não podia ser entendida até sua recente descoberta. Em sua narrativa, a primeira indicação dessa descoberta de ser intersexo foi a conversa com sua tia, que contou que ela nasceu intersexo depois que seus pais faleceram. No entanto, somente essa conversa não torna possível o entendimento completo desta descoberta. É necessário que esse entendimento seja mediado pelas "informaçóes" adquiridas por vários meios, como ela relata: "eu só fui entender isso agora, porque daí eu comecei a estudar na internet e saber, eu tinha visto um documentário uma vez".

Se a conversa com a tia e as informaçóes conseguidas via internet e em documentários mudaram seu entendimento de si mesma, os eventos com médicos parecem ter um grande peso em sua narrativa para legitimar essa descoberta. É assim que Carla retoma o exame de ultrassom acontecido em 1999, pois ele confirma uma ambiguidade que sempre esteve lá. Carla procura se aproximar do status de irrefutabilidade do saber médico e daquilo que permeia o científico. A narrativa do evento com a psicóloga vem corroborar ainda mais essa descoberta de ser interse$x o$. A fala da psicóloga, perguntando se ela tinha útero, a faz lembrar do exame de ultrassom de 1999, e como em um insight psicanalítico, Carla "entende" sua questáo. O desconhecimento da psicóloga da sua descoberta de ser intersexo torna mais fidedigna sua fala e fornece mais um ele- 
SUJEITOS, CONVENÇÓES E DIFERENÇAS EM NARRATIVAS $\mid 53$

mento de cientificidade a seu argumento. É interessante notar que, se Carla nasceu com pênis e útero, não foi o pênis do ambíguo que foi confirmado na pergunta da psicóloga. Carla se sente como pessoa que tem útero, e não como "pessoa que tem pênis". Eventuais sentimentos masculinos não são confirmados. O que ela salienta são sentimentos que advêm do órgáo considerado por muitos "o mais feminino": o útero.

Deste modo, argumento que, mais do que "mudar", essa descoberta concede um lugar a uma feminilidade que sempre esteve fora do lugar. Uma feminilidade deslocada em um corpo nascido com pênis é confirmada pelo útero. O sentido dessa confirmação do útero fica mais evidente quando ela relata que a descoberta de ser intersexo mudou sua vida, pois ela sempre se considerou um homossexual efeminado que queria ser mulher.

Carla também recebeu a confirmação da psicóloga de que não se classificava nem como travesti, nem como transexual. O fato de ela sentir como pessoas que tem útero faz com que seu problema não resida em um nível psicológico do se sentir mulher, como para as travestis e transexuais, e sim para um nível biológico do ter útero. Carla utiliza, como já argumentei, justamente o discurso que constrói travestis e transexuais como "abjetas", isto é, uma não correspondência entre sexo e gênero. Argumento, assim, que toda essa incerteza de se classificar, envolvida neste nível do se sentir, é convertida em "certeza” pela sua "ambiguidade de corpo". Como ela relata:

Carla: É o que eu te falei, a descoberta do intersexo me deixou meio sem rumo. Então, eu já fui homossexual, eu já fui travesti, eu fui transexual, e agora eu sei que sou intersexo, pelo menos isso eu tenho uma certeza física, não tá no subjetivo.

Bruno: Me fala mais sobre isso, porque a transexualidade seria mais subjetiva?

Carla: É, ainda é, não tem nenhum estudo nem na antropologia, na psicologia, o que é um transexual? Tá, é uma pessoa, e aí, a medicina se apode- rou dizendo que é doença, uma disforia. Eu não concordo, eu não sou doente, eu acho que isso tudo é uma necessidade de controle, nada mais do que isso. Agora, se a pessoa transexual se sente na necessidade de se realizar com uma operação, opere, eu quando tinha o nariz grande me operei, pra me sentir melhor. Agora, eu não posso me considerar mais nada, porque agora eu sei o que eu sou, o que eu sempre pensei que era, a certeza que eu sempre tive era essa, ser dois em um, eu sou intersexo, eu tenho os dois, as duas características.

Carla póe em questão a concepção médica sobre transexualidade, pois se considerava transexual, mas não queria se operar para [se] sentir melhor. Ela reage à noção médica que considera a transexualidade uma doença e que atrela o desejo pela cirurgia a essa experiência ${ }^{5}$. Segundo Carla, isso tudo é uma necessidade de controle.

$\mathrm{Na}$ argumentaçáo de Carla, ser travesti e ser transexual são questôes de se sentir mulher, ao passo que ser intersexo é uma certeza física que lhe permite liberar-se de considerações "subjetivas", de se sentir ou de "se considerar" isso ou aquilo: Agora, eu não posso me considerar mais nada, porque agora eu sei o que eu sou, o que eu sempre pensei que era, a certeza que eu sempre tive era essa. Essa certeza pressentida foi confirmada pela descoberta de ser intersexo. Essa figura do ser andrógino, do dois em um, vivenciada em suas experiências anteriores de ser homossexual, travesti, transexual, e elaborada pelas suas leituras e pesquisas, possibilita-lhe se colocar nesse lugar de alguém que é dois em um, e portanto sempre aberto a mais de uma possibilidade. Penso que há aqui uma interlocução com a literatura das ciências sociais e com sua trajetória como performer, na qual sempre quis valorizar a androginia, além de uma percepção de uma atual valorização da "diferença". A figura do sujeito ambíguo, do andrógino, é articulada pela descoberta de ser intersexo, o que lhe dá um tipo de capital corporal para poder se colocar nesse 
lugar, já que ela seria a corporificação dessa ambiguidade, como relata em alguns momentos a prova fisica da diversidade.

Acredito que o sentimento que Carla relata com a descoberta de ser intersexo que a deixou sem rumo parece de fato "dar um rumo" a ela, pois articulou e deu novo sentido ao descompasso das categorias e aos problemas que ela percebia ao se identificar. Ser intersexo possibilita-lhe identificar-se de várias formas. De certa forma, a retórica literalista volta-se contra si mesma, pois se um de seus efeitos seria a naturalidade, no caso de Carla trata-se de uma naturalidade ambígua, aberta a diferentes possibilidades. Vejamos a parte de sua narrativa em que ela discorre sobre as práticas sexuais de sua preferência:

Bruno: Atualmente, qual a prática sexual que você mais gosta?

Carla: Eu sempre fui passiva, eu nunca gostei de fazer a ativa não, já fiz algumas vezes. Se for pra fazer ativa, eu faço com mulher, com a mulher eu sou macho, com um homem eu sou fêmea, entendeu? Eu acho que isso tem tudo a ver com a minha questão de intersexo, eu acho. Porque, eu nunca me senti assim, eu nunca quis ser mulher, entendeu? Nunca pensei em me operar, mas eu sempre me senti andrógino, mesmo quando eu não sabia nada dessas questôes, que não se falava dessas questôes de transexualidade. Nos anos 70, não se falava de transexualidade, falava de homossexualidade, mas é muito pou$\mathrm{co}$, a gente sabia que era viado e pronto, nunca tinha discussão sobre sexualidade. A discussão sobre sexualidade veio nos anos 80 , pelo menos aqui no Brasil. Mas, sempre assim: quem sou eu? Essa pergunta, todo mundo faz essa pergunta, né? Quem sou eu? O que eu sou nesse mundo? E eu sempre pensei: eu sou andrógino, eu sou dois em um. $\mathrm{E}$ isso assim foi confirmado agora em 2004, que eu fiquei sabendo que nasci intersexo, eu sou dois em um, eu tenho pinto e tenho útero, né, e isso é indiscutível.
Essa pergunta foi feita diversas vezes, pois sempre que eu perguntava para ela sobre preferências de práticas sexuais, ela me relatava que gostava de tudo, que não tinha nenhuma preferência. De fato, não ter certas preferências, e se dizer pansexual, como em alguns momentos, a coloca como uma pessoa "sem preconceitos", como a prova física da diversidade. No entanto, uma vez que ela respondeu que com a mulher eu sou macho, com um homem eu sou fêmea, procurei inquirir mais acerca dessas suas relaçóes sexuais com mulheres. Carla contou que teve poucas relaçôes sexuais com mulheres e que nunca teve relacionamentos afetivos com elas. Assim, se em vários momentos ela queria marcar esta sua diversidade nas escolhas e práticas, e uma desarticulação entre gênero e sexualidade, na fala acima, em que ela relata acerca de suas práticas sexuais, as relaçóes entre gênero e sexualidade tornam-se mais rígidas.

Carla relaciona a prática de ser passiva ao feminino que escolheu viver. Eu sempre fui passiva e, segundo ela, isso tem tudo a ver com o fato de ela ser intersexo, pois ela nunca quis ser mulher. $\mathrm{O}$ fato de não querer ter operado e ter continuado com o pênis articula-se com a descoberta de ser intersexo, pois ela é dois em um. Feminina por escolha de gênero, e pela "descoberta do útero", que em alguns contextos se articula com a prática sexual de ser passiva; e masculina, pois continua com o pênis, o símbolo privilegiado (e aparentemente único) que, em sua narrativa, representa o lado da masculinidade.

Ainda segundo Carla, antigamente o que ela sabia é que era viado; a discussão de transexualidade veio depois. A categoria transexualidade sempre é marcada como este depois, como um modo mais "correto e científico" de falar dessas experiências de pessoas que praticam transformaçóes de gênero por estar aliada e embasada pelo saber médico. Assim, o "nós" de Carla abarca transexuais e travestis, que antes eram vistas como todos viados. Intersexo, transe- 
xual e travesti aparecem assim como categorias que não são excludentes entre si.

Práticas e preferências sexuais são rearticuladas com esta descoberta. O que Carla mostra é que o contato com novas classificaçóes e convenções sobre sexualidade e gênero transformam a forma como se entendem sentimentos, desejos e preferências sexuais. Carla diz que sempre foi passiva, e o fato de ser intersexo explica porque ela nunca quis se tornar uma "mulher com vagina". Ela não se "sentia" travesti e, segundo as convençôes médicas, não se classificava enquanto transexual, pois não queria a operação de mudança de sexo. De fato, a descoberta de ser intersexo transforma incertezas e descompassos diante das categorias em uma "certeza" física e indiscutível que, por sua vez, abre possibilidades múltiplas de usos de categorias.

\section{“Quando você se diz trans": narrativa de Bárbara}

Se a narrativa de Carla é organizada a partir da descoberta de ser intersexo, a narrativa de Bárbara é organizada em torno das tensóes entre travestis e transexuais, que marcam sua situação presente. $\mathrm{O}$ uso que Bárbara faz da categoria transexual nos informa acerca de questôes relevantes sobre o processo de agenciamento de convençóes. Segundo ela:

Eu hoje acho muito estranho, porque quando você se diz "trans", há uma transformação na sua anatomia, não interna, que é o caso das transexuais. Para mim, transexual é o cidadão que se submete a uma operação e desfaz de seus órgãos genitais. Isso pra mim é transexual. Hoje, tem um discurso que transexual é a pessoa que transforma o corpo, através de prótese mamária, silicone no quadril e por aí vai, né, tomar hormônio todo dia, a transexual é isso. Quer dizer, as pessoas não se enquadram mais naquela coisa de travesti. Transexual agora é tudo isso, e eu vou me identificar que nem uma dinossaura? A jurássica na história? Agora, eu também falo que eu sou transexual. Aí, tem gente que fala que não, né. Mas a visão que eu tenho da transexual é isso. Eu seria travesti na história, né, porque toda a minha transformação, né, pode ser revertida.

Bárbara póe em evidência as convençôes "hegemônicas" acerca das diferenças entre travestis e transexuais e, no entanto, as rearticula por um discurso geracional e um aspecto de "novidade" da transexualidade. Em sua narrativa, Bárbara diz que seria travesti na história, isto é, tomando como base de definição as categorias médicas, e aponta uma dimensão geracional na discussão, afirmando que as pessoas não se enquadram mais naquela coisa de travesti. Ela aponta mudanças nas convençóes do termo transexual, operadas pelas novas geraçôes. "Antes", segundo sua narrativa, transexual [era] o cidadão que se submete a uma operação e desfaz de seus órgãos genitais, no entanto, hoje tem um discurso que transexual é a pessoa que transforma o corpo, através de prótese mamária, silicone no quadril e por aí vai, né.

Ela sinaliza um alargamento do sentido do que é transexual, apontando que transexual seria toda a forma de transformação corporal. Deste modo, diferentemente de Carla, aqui parece haver (nos termos de Crapanzano, 2002) uma valorização de um estilo de interpretação retórico e da dimensão pragmática dos sistemas de classificação. A lógica por trás dessa argumentação parece ser que as convençóes e as categorias podem mudar, elas não são fundamentadas numa certeza natural, e assim dependem do contexto e da forma como são utilizadas. Em sua narrativa, é o alargamento da categoria transexual que lhe permite identificar-se como transexual. Não se trata, no entanto, somente de uma mera mudança de palavras, pois as pessoas não se enquadram mais naquela coisa de travesti. Em outro momento de sua narrativa essa questão fica mais evidente: 
56 | Bruno Cesar Barbosa

Essas novas têm que respeitar muito a gente, a nossa geração, porque nós abrimos caminho pra elas, elas não têm noção e eu ouvi esses dias uma coisa horrorosa. [...] Hoje em dia, tem uma cultura de rapazes bem nascidos, que viveram suas vidas, concluíram sua faculdade, têm trabalho, e um dia eu ouvi uma usuária daqui falando que tinha que higienizar os travestis. [...] Sei lá o que ela quis dizer de higienizar, porque ela dizia: "os travestis não servem pra nada, não sabem se comportar". Porque a gente servia a causa quando precisava de gente que sirva a causa, de que modo eu não sei. Porque antes, que não tinha nenhuma dessas beldades operadas, a gente batia de frente e enfrentava a discriminação, agora higienizar travestis, a gente que higienizava lá nos anos 1960. A gente que abriu as portas, quem é que deu a cara para bater? Homossexual podia ir em qualquer lugar. Agora, travesti não.

Bárbara marca neste relato de "quem" ela está falando, isto é, das beldades operadas. Marca também certos aspectos de classe: rapazes bem nascidos, que viveram suas vidas, concluiram sua faculdade, têm trabalho; e se coloca neste momento de onde fala, da posição de travesti. No entanto, a questão é mais tênue, pois Bárbara não considera as transexuais como estes "outros". A comunidade imaginada ${ }^{6}$ (Anderson, 2005) construída por ela permite que as transexuais sejam entendidas como do seu "grupo". Neste sentido, Bárbara aponta que sua relação com estas beldades operadas náo é de alteridade, tanto que elas podem ser a nova geração.

Esta nova geração seria uma geração ingrata com as conquistas da geração anterior. Quando Bárbara aponta esta questão acerca de higienizar os travestis, ela estava se referindo a um evento ocorrido no dia da entrevista e a um processo mais amplo de estigmatização das travestis. Segundo ela, as travestis só aparecem na mídia e nas falas das pessoas ligadas a escândalos e marginalidade. Como ela narra, em uma reunião entre travestis e transexuais, algumas transexuais falavam que as travestis não sabiam se comportar nas reunióes e era melhor elas não participarem. As travestis seriam vistas como escandalosas, podendo inclusive ser agressivas. Segundo Bárbara, é neste contexto que algumas transexuais teriam utilizado a expressão higienizar os travestis, e ela se sentiu extremamente ofendida com este evento. Percebe-se o uso do artigo masculino na locução higienizar os travestis, como uma forma de ofensa por uma hierarquia de gênero na qual o feminino é que assume a posição superior, o valor englobante. Tal ofensa marca a falta de uma feminilidade desejada, ou a presença de uma feminilidade falsa, de quem náo sabe se comportar, já que travestis não seriam rapazes bem nascidos.

Bárbara refere-se ironicamente às transexuais como rapazes, destacando com isso o fato de terem nascido homens como elas, as travestis. Bárbara utiliza o mesmo princípio de ofensa utilizado por parte das transexuais contra ela, e assim as chama de rapazes. No entanto, tal uso é irônico, pois Bárbara emite tal enunciado da posição de travesti, que seriam qualificadas como mais masculinas, já que seriam os travestis. Sua ação, assim, marca uma relação de não alteridade entre travestis e transexuais, pois as duas teriam nascido homens. Em sua narrativa a construção do que é travesti está intrinsecamente ligada à categoria transexual. E é assim que atributos de gênero, classe e geraçáo intersectam-se na produção das diferenças. Bárbara marca certos contornos de classe à categoria transexual, pois este lugar transexual é dos rapazes bem nascidos, que concluiram suas faculdades, têm trabalho. Marca também como a cirurgia de transgenitalização está atrelada à categoria transexual, ao apontá-las como as beldades operadas, questão utilizada por muitas transexuais para reivindicarem que sua feminilidade é mais natural do que a das travestis. Portanto, dizer que agora, eu também falo que eu sou transexual 
SUJEITOS, CONVENÇÓES E DIFERENÇAS EM NARRATIVAS $\mid 57$

é querer se aproximar deste outro lugar, diferente do lugar travesti, que em sua narrativa é marcado pela estigmatizaçáo e marginalidade. Esse lugar transexual "tem" classe, sabe se comportar e, deste modo, possui também outro tipo de feminilidade. Os termos adquirem também aspectos de geração, já que as travestis são as jurássicas, e a categoria das novas gerações é a transexual. Portanto, dizer-se transexual também a coloca como uma pessoa "informada” acerca das mudanças atuais.

Aqui, travesti e transexual parecem se assemelhar ao que Facchini (2008) chamou de "operadores sociais da diferença” ao pensar em estilos, identidades e classificaçóes. Estes termos articulam os marcadores sociais da diferença como gênero, sexualidade, classe e geração. As categorias travesti e transexual em sua narrativa tomam sentido pela articulação de convenções destes marcadores.

Como argumentei, na narrativa de Bárbara não existiria relação de alteridade entre travestis, transexuais e homossexuais. Todos fazem parte da mesma comunidade imaginada. $\mathrm{O}$ uso que Bárbara faz do termo terceiro sexo nos explica mais essa questão:

Terceiro sexo é uma coisa lamentável, mas também existe, porque eu não sei qual é o primeiro e qual é o segundo, mas existe, porque você há de convir que existe a mulher, existe o homem e existe o homossexual. Então o homossexual não é o primeiro sexo, agora o heterossexual que discuta entre eles quem é o primeiro e quem é o segundo. Se é o homem ou se é a mulher.

Terceiro sexo e homossexual, menos do que a "identidade homossexual", parece definir aqui tudo que é diferente de heterossexual. Quando Bárbara chama as transexuais de rapazes, argumenta que elas também são homossexuais como ela. Afinal, como bem explicado nesta última fala: existe a mulher, existe o homem e existe o ho- mossexual. Durante a entrevista resolvi perguntar mais o que seria esse homossexual do terceiro sexo:

Bruno: E o homossexual que faz parte do terceiro sexo, ele seria só o homossexual mais afeminado, com características femininas e, neste sentido, o homossexual mais "ativo", masculino, entraria no terceiro sexo?

Bárbara: $\mathrm{O}$ terceiro sexo é assim, ele é homossexual, ele se relaciona com a pessoa do mesmo sexo. Determinadas tendências têm a ver mais com o fetiche. Eu sou homossexual, eu não acredito muito nessa história, a gente não vai ficar discutindo: eu quero ser sodomizado, eu vou sodomizar. Porque pra mim chegou nesse ponto é melhor a gente náo fazer nada. Porque eu acho que relação sexual começa com o olhar, no diálogo que existe, nas carícias, e há pessoas que são mais fortes, predominantes, porque elas atuam de uma maneira que as pessoas chamam de ativa, porque o fato de eu ser penetrada ou de eu penetrar não quer dizer que eu seja mais passivo, eu posso ser muito mais atuante, ser mais ativa, quando eu falo: me penetre. Então eu acho que essa relação de ativa/passiva náo existe, não faz sentido. Ao meu ver, é claro, eu estou falando da minha sexualidade, da maneira como eu vejo a minha sexualidade. Eu sou homossexual. Mas eu náo posso dizer de como você se sente, se você de repente, você se sente transexual, você tem anseios transexuais. Falar do coletivo, sobretudo em sexualidade, é muito difícil, é muito complicado.

O terceiro sexo é de pessoas que se relacionam com o mesmo sexo. Assim, o que define homossexual é a relação entre duas pessoas do mesmo sexo, entendendo sexo a partir das genitálias ao nascer. Visto que no relato anterior Bárbara aponta que transexuais são homossexuais, sexo é apontado como algo que não se muda, nem com cirurgia. Procurei investigar nesta pergunta também se este homossexual do 
terceiro sexo englobava o "homossexual que é ativo e masculino". Segundo Bárbara, determinadas tendências, como querer ser sodomizado ou sodomizar, querer ser mulher ou viver em um "outro" gênero, têm relação com um fetiche. Ela também desloca a ideia de que ser penetrado é necessariamente ser passivo, pois relata: eu posso ser muito mais atuante, ser mais ativa, quando falo: me penetre.

Bárbara termina esse relato apontando que é muito difícil falar do coletivo em relação à sexualidade. Vemos que é, sobretudo, sexualidade, e não gênero, a categoria para explicar suas práticas. Assim, ela aponta que é homossexual, mas náo pode falar dos outros, pois alguém pode se sentir transexual ou ter anseios transexuais. É interessante notar aqui como a categoria transexual surge como um anseio e sentimento, e não tanto como algo que se é, algo fixo, pois afinal todos seriam homossexuais.

A partir destas perguntas chegamos à discussão sobre seus relacionamentos afetivos e sexuais atuais. Como ela relata:

Bárbara: Esses meninos que procuram as travestis mais velhas procuram elas porque eles têm medo das travestis da rua. Os homens também são sensíveis, eles também têm medo da primeira vez com alguém, e as travestis da rua intimidam esse menino, e eu não, eles até me tratam como tia. Eu acho que tem uma relação maternal sabe? Para ter um relacionamento tem que ser mais que físico, tem que rolar uma comunicação de intelecto. É importante conversa, que role uma troca, sabe?

Bruno: Então, muitas coisas mudaram em relação a sua sexualidade?

Bárbara: Eu acho que mudou, assim, porque os homens que se relacionavam com a gente antigamente, eles até poderiam ter anseios de ter uma relação mais completa, mas eles não ousavam, então a nossa relação era passivo-ativo, e a gente era a passiva da história e tínhamos uma relação incompleta. Hoje não, hoje a relação é bem aberta, então a gente se realiza plenamente, sexualmente, hoje. Com esses meninos tanto faz ser ativa ou passiva, hoje os homens procuram uma travesti porque eles também querem ser penetrados, caso contrário, eles procurariam uma mulher, pois antigamente fazia sentido buscar travesti para ser ativo com elas porque na década de 1960 só se trepava com uma mulher depois de casar, assim os homens iam atrás das bichas e travestis. Agora hoje não, né, as mulheres são todas saidinhas. Mas como eu te disse, eu não acho que sou menos feminina como ativa e o homem não deixa de ser menos masculino como passivo.

Bárbara sinaliza diferenças em relação aos homens com os quais ela se relacionou durante sua vida, colocando-se neste relato na posição de travesti. Segundo ela, antigamente a relação com os homens era incompleta, isto é, ela era a passiva, o homem era o ativo e a relação era somente sexual. Atualmente Bárbara aponta ficar com garotos mais novos, que a procuram para relacionamentos afetivos. Com estes, suas relaçóes são mais completas, isto é, é possível desempenhar ambas as práticas sexuais e a relaçáo não se limita a esses aspectos sexuais.

Ela aponta diferenças em relação a este homem que procura travestis atualmente fazendo relaçóes com a disponibilidade de sexo das mulheres. Segundo ela, nos dias atuais, os homens procuram as travestis principalmente para serem penetrados por elas. Antigamente os homens procuravam travestis para serem ativos, pois só se trepava com uma mulher depois de casar. Se as relaçóes geracionais são fonte de tensóes e disputas, como ela nos aponta em relação às beldades operadas, quando ela nos relata acerca de seus relacionamentos afetivo-sexuais atuais, são relaçôes intergeracionais que são investidas de prazer. Atualmente Bárbara se relaciona com homens mais novos e pode inclusive manter relaçôes sexuais ativas com eles, deslo- 
cando neste sentido práticas sexuais e gênero, isto é, a relação entre passividade e feminilidade, diferentemente da narrativa de Carla.

Bárbara nos relata que seria identificada como travesti, pois toda a sua transformação corporal pode ser revertida. Disse se reconhecer transexual, mas segundo ela mesma, uma transexual falaria que ela não é trans e sim travesti, pois não fez cirurgia de transgenitalização, e nem a deseja. No entanto, ela busca reconhecimento por meio do que a categoria transexual representa, isto é, um lugar diferente da categoria travesti. Na narrativa de Bárbara, entendo que as diferenças entre travestis e transexuais são menos do que diferenças em essência, do que signos de diferenças de classe, geração, gênero e sexualidade. O lugar transexual aparece como o lugar dos rapazes bem nascidos, superior ao lugar marginal das travestis. É esta posição de classe, ligada a um tipo de feminilidade, que Bárbara almeja, assim como uma fuga do lugar marginal e escandaloso das travestis.

\section{"Assumir a travestilidade": narrativa de Renata}

Assim como nas outras narrativas discutidas, a narrativa de Renata está organizada em torno da situação atual de sua vida. Renata se assumiu travesti, ou sua travestilidade, há dois anos e tem participado ativamente na militância, caminho pelo qual disse ter encontrado um espaço para ser travesti. É o assumir a travestilidade que dá o sentido global e a coerência do eu em sua narrativa, e esta circunstância a faz redimensionar eventos passados de discriminação. Assim, logo após sua apresentação, ela se póe a contar o que ela chama de histórico de repressáo a sua travestilidade.

Renata aponta uma série de eventos de preconceito, discriminaçáo e violência que retardaram suas tentativas de ser travesti. No entanto, aponta saídas denominadas furtivas, nas quais ela procurava viver sua travestilidade:
[...] eu fui linchado aos 18 anos, eu havia me montado e eu fui passear numa rua, viver minha travestilidade, fui passear de madrugada em uma rua bem deserta, onde as travestis faziam ponto, e um grupo de rapazes me viu, identificou que eu estava montada, que eu era um menino montado de mulher, e eles me pegaram e me lincharam. [...] Então, a gente morria de medo de fazer qualquer experiência de sair na rua montada, de sair para uma boate, e eu acabei sepultando tudo, eu acabei levando uma vida masculina, e nunca pensei que eu ia chegar um dia e achar que o melhor para mim era me assumir travesti. Eu cheguei a essa conclusão sólida, concreta e hoje eu estou bem feliz como travesti. [...] Eu tinha uma compulsividade toda de exercer minha travestilidade. Eu ia em aniversários, por exemplo, e eu não podia beber, começava a beber me dava uma vontade de me montar, e não foram poucas vezes que eu roubei calcinhas e ia no banheiro vestir a calcinha. Minha vida sempre foi assim, até que eu comecei a me assumir.

Essas tentativas de se montar eram colocadas no segredo, não eram contadas à família, nem aos amigos próximos. A estratégia do segredo a fazia tomar algumas iniciativas para não descobrirem tais práticas, uma vida masculina, como Renata nomeia. Em suas palavras:

Renata: Era tanto medo de que as pessoas descobrissem que eu desenvolvi uma voz bem masculina, um jeito de andar bem masculino. Casei, tive filhos.

Bruno: Então, você se via como heterossexual? Renata: Sim, eu sempre me passei por um homem heterossexual.

Bruno: Você disse que exercia esse homem heterossexual, mas para você em segredo você vivia sua travestilidade. Como você via esse desejo de se vestir de mulher? Você se classificava de alguma forma? Isso entrava em confronto com o fato de você se dizer heterossexual? 
6o | Bruno Cesar Barbosa

Renata: Engraçado isso que você perguntou. Eu nunca me achei menos homem com as mulheres pelo fato de ser travesti. $O$ fato de ser travesti nunca me tirou a autoestima de homem heterossexual que eu tinha. Porque eles não sabiam de nada, eu não deixava eles saberem, absolutamente nada. É engraçado, eu nunca me senti homem, né, nunca me senti mulher, sempre me senti enquanto travesti. Mas como travesti descobri que posso ficar com mulheres, mesmo que as travestis olhem torto.

Bruno: Nunca você pensou que fosse homossexual?

Renata: Eu nunca me senti homossexual. Eu sempre achei que eu tinha uma personalidade heterossexual com uma tara. E aí eu descobri que essa tara é minha identidade, eu sou muito mais feliz feminina do que masculina.

Bruno: Mas você tinha desejo por outros homens? Renata: Tinha, tinha.

Bruno: E isso não fazia você achar que era homossexual?

Renata: Não, porque eu achava que podia manter uma vida heterossexual casado. Eu achava que tudo era fetiche, o desejo por homens e ser travesti.

Em sua narrativa o uso do termo travesti sempre aparece substantivado como: ser travesti, minha travestilidade. Assim, quando ela fala como ela se via antes de se assumir travesti, ela relata o seguinte: eu sempre me passei por um homem heterossexual e o fato de ser travesti nunca me tirou a autoestima de homem heterossexual que eu tinha. O homem heterossexual é visto como um papel desempenhado pelo medo e pela fuga da estigmatização de ser travesti. A possibilidade de ser travesti era abafada pelo homem heterossexual, que mais do que somente uma orientação sexual, é um estilo de vida masculina, casado e com filhos.

Como nas outras narrativas, a situação presente do seu assumir-se travesti a faz olhar suas experiências passadas e reconfigurá-las a partir dessas lentes atuais. Assim, os eventos em que o desejo de ser travesti foi maior que o medo são importantes em seu argumento. Ela aponta que eu nunca me senti homem, né, nunca me senti mulher, sempre me senti enquanto travesti. Renata está construindo sua "verdadeira essência”, rastreando o passado em busca de elementos que comprovem que ela sempre foi travesti. Assim, há tensóes e contradiçóes no que diz respeito às múltiplas posiçóes ocupadas por ela.

Quando Renata olha seu passado, ela convive com o fato de que entendia tais práticas como perversão e com a atual ressignificação dessas práticas. Em seu relato, ela aponta que achava que era um homem heterossexual com uma tara. Nas palavras de Renata:

Eu achava que isso era uma perversão, que era algo perverso, que não fazia parte de mim, que era uma espécie de uma tara, uma coisa de um lado desequilibrado, que eu não deveria contar para ninguém. Eu nunca pensei que uma travesti pudesse viver com cidadania, eu achava que a travestilidade era um descaminho, uma coisa de gente marginal, até que as coisas foram amadurecendo, começou a haver aqui no Brasil alguma cidadania para travestis e transexuais nos anos 90 . E eu comecei a amadurecer, amadurecer, comecei a fazer terapia, comecei a ler muitos livros, comecei com os livros mais conservadores de psicólogos e psiquiatras, depois passei para as ciências sociais, e comecei a criar coragem, comecei a ler biografias de travestis e transexuais e aí eu fui percebendo que o meu melhor caminho seria seguir minha travestilidade com orgulho, sem medo, com autoconfiança, tentando me convencer cada vez mais que essa poderia ser uma experiência bonita, uma experiência saudável, de verdade.

$\mathrm{O}$ "eu" travesti atual de Renata procura dar conta dos seus outros "eus". O preconceito, estigmatização e violência contra travestis são um 
SUJEITOS, CONVENÇÕES E DIFERENÇAS EM NARRATIVAS $\mid$ 6I

dos motivos agenciados desse "abafamento" do ser travesti, que não se configurava enquanto vida possível até seu atual assumir-se. Assim, ser travesti e gostar de fazer sexo com outros homens seria naquela época visto por ela como uma perversão.

Em outros momentos de sua narrativa, Renata procura destacar os elementos que tornaram possível essa mudança de visão em relação a suas práticas, tais como: fazer psicoterapia, ler livros especializados, um contexto político mais favorável e a aposentadoria. Em relação à procura de saberes, seu primeiro acesso a leituras especializadas foi o saber médico-psiquiátrico e depois passou para as ciências sociais, por onde a categoria travestilidade passa a ser utilizada, com orgulho. A busca de (re)conhecimento a faz olhar para suas práticas e mudar seu sentido, entendê-las agora com orgulho. Renata explica mais por quais meios teve acesso a essas informaçóes:

Uma mudança que foi importante, que ajudou, foi a internet, eu me lembro que com 35 anos eu descobri a internet, um grupo chamado Brasil Cross-Dresser Club, um grupo que é sediado em São Paulo, que reúne pessoas que se identificam como homens, mas que têm um determinado horário para exercer sua travestilidade. [...] Eu comecei a participar desse grupo, as CD (abreviação de cross-dresser) sessions, as sessóes de transformação, que eles fazem até hoje, e eu fiquei um tempo sendo sócia desse clube, e fiquei vivendo como CD, Cross-Dresser, nesse período. [...] Assim que eu comecei a descobrir os primeiros livros de travestis e transexuais eu comecei a detoná-los, eu comecei a sentir conforto assim, eu comecei a perceber que aquela visão assim que eu tinha, que eu era pervertida, perdida na vida, eu comecei a ver que isso era preconceito. [...] Aí na época eu comecei a ler, li o Geraldo Campos, os caras mais tradicionais, Money, Benjamin. Claro, assim, a gente sabe hoje, a visão toda desse pessoal é uma visão conservadora, é uma visão patologizante para as travestis e transexuais, mas também já foi um grande avanço. Eu deixei de me achar uma pessoa pecaminosa e comecei a me achar uma pessoa doente, uma paciente da psiquiatria. Isso para mim já foi um avanço. Eu me sentia meio desculpada. Não, eu tenho um transtorno, eu pensava, eu não sou puta. Eu não sou pervertida. Eu tenho um transtorno e eu tenho que tratar esse transtorno para eu me sentir mais tranquila. Eu pensava que se eu tratasse de tal transtorno eu tinha uma possibilidade de cidadania, de dignidade, mas ainda não uma possibilidade de felicidade.

O primeiro caminho que Renata relata que seguiu para conseguir informaçôes foi pela internet, por onde ela conheceu o Brasil Cross Dresser Club (BCC), onde, por sua vez, obteve livros especializados no assunto. Renata aponta aqui como a leitura desses especialistas psiquiatras, e sua colocaçáo como paciente, promoveu um grande avanço, pois fez com que ela se deslocasse de um lugar do pecado para um lugar da doença. Eu não sou puta, eu não sou pervertida, eu tenho um transtorno, ela relata. O BCC é apontado como um ambiente seguro onde era possível realizar sessóes de transformação. No entanto, Renata aponta seus descontentamentos com o BCC:

Eu não me contentava com aquele clube. Aquele clube era muito pouco. O pessoal se contenta em viver uma vida sem hormônios femininos. Eu percebi entáo com o passar do tempo que eu não era cross-dresser, que eu era mesmo uma travesti. Mas esse grupo de cross-dresser foi o primeiro porto seguro que eu encontrei para me tornar uma travesti. Um clube de pessoas idôneas, todos muito bem posicionados na vida, gente digna, e tá todo mundo ali tentando viver o seu problema, a sua travestilidade, e uma preocupaçáo de náo prejudicar todo um passado vivido com família, com profissão. Mas eu não tinha muito a perder. Eu era um professor, eu não tinha patrimônio, meu filho já estava 
$62 \mid$ Bruno Cesar Barbosa

criado, aí eu pensava por que eu vou ficar me guardando, eu quero ser travesti, eu quero ser travesti o dia inteiro.

Ela não queria somente ser travesti poucas horas na semana, no entanto, ela sabia que viver vinte e quatro horas como travesti demanda efeitos práticos em sua vida. Ser travesti é, em sua narrativa, se desligar do estilo de vida masculino, homem heterossexual, casado e com filhos, ou, como ela fala em outros momentos, valores pequeno-burgueses. Renata aponta que não tinha muito a perder, pois ela não tinha patrimônio, o filho já tinha sido criado, além de ter conseguido se aposentar. Segundo Renata, as cross-dressers não estariam dispostas a largar estes valores pequeno-burgueses, a vida masculina, pois teriam muito mais a perder que ela, já que seriam de classes mais elevadas, teriam patrimônio, e toda uma história de vida masculina, casado e com filhos. Ser travesti, em sua narrativa, aparece como um processo de afastamento desses valores pequeno-burgueses.

Narrativas autobiográficas geralmente misturam diversas temporalidades a partir de certas lentes atuais, como apontei na introduçáo deste artigo. Primeiramente, Renata aponta suas primeiras transformaçóes com as CDs. Com elas, aprendeu sobre dicas de maquiagem, mas das transformaçóes mais intrusivas como hormônios só foi ter conhecimento na boate e na rua. Se Renata foi procurar tais informaçóes com outras travestis em boates e na rua, tal meio de acesso a deixou preocupada. Renata queria tomar hormônios, só que ficava preocupada com essa coisa de tomar hormônio, porque cada travesti que conhecia na rua tomava um tipo de hormônio e por conta própria.

A procura por uma forma de tratamento mais adequada, isto é, com acompanhamento médico, fez Renata procurar o Programa de Reabilitação e Orientação Sexual (PROsex), que realiza triagens para a cirurgia de transgenita- lização no Instituto de Psiquiatria da USP. No entanto, sua entrada no PROsex a fez perceber que não seria tão fácil conseguir essas informaçóes sobre hormonização. Renata sinaliza que quando foi procurar esse serviço ainda tinha dúvidas se era travesti e transexual, e não sabia que o fato de não ser identificada como transexual poderia barrar-lhe o acesso ao tratamento endocrinológico. A passagem pelo PROsex marcou mais um momento de sofrimento e preconceito nesse processo de se tornar travesti. Se Renata se refere a esses momentos como o começo de seu assumir-se com esta certeza atual de ser travesti, a narrativa do evento do PROsex evidencia incertezas diante do se classificar, assim como a conversão dessa incerteza em certeza pelo diagnóstico médico, sinalizando que Renata não seria transexual, sendo assim travesti.

Esses eventos marcam seu afastamento desse saber médico-psiquiátrico, considerado, como já discorrido, conservador. Renata procura formas mais positivas de entender suas práticas. É nesse sentido que as ciências sociais entram em sua narrativa. De um modo patologizante da medicina, que como ela aponta possibilitou um conforto, ela encontrou formas mais positivas de entender o que é ser travesti. Segundo Renata:

Eu só comecei a perceber que ser travesti poderia ser uma coisa feliz quando eu comecei a ler sociólogos e antropólogos. Aí sim eu comecei a perceber que ser travesti é um fenômeno. Uma experiência identitária. E não necessariamente uma doença, um transtorno, um distúrbio, um desequilíbrio. Só porque eu não sou igual à maioria? Só porque eu gosto de ser mulher? Só porque eu nasci com pênis e gosto de ser mulher? Eu acredito que a travestilidade pode ser uma experiência legal, bonita, uma experiência de encontro consigo mesmo, uma experiência de uma alma que estava trancada, porque eu sou uma alma travesti que estava trancada. 
SuJEITOS, CONVENÇÓES E DIFERENÇAS EM NARRATIVAS $\mid 63$

A leitura dos antropólogos e sociólogos ${ }^{7}$ a fez perceber que ser travesti não é um transtorno, um distúrbio, um desequilíbrio, mas sim um fenômeno, uma experiência identitária. Ela não é igual à maioria, que é heterossexual. Mas isso não faz dela um distúrbio. $\mathrm{O}$ uso do termo travestilidade vem desse processo reflexivo de Renata do discurso antropológico, sociológico e da militância. Renata relata o uso da internet, onde descobriu o BCC. Ela também aponta sua aproximação da militância LGBT, pela Associação da Parada do Orgulho LGBT (APOGBLT), na Secretaria de Travestis e Transexuais. Ela também começou a participar das reunióes das Terças Trans, de grupos, e também das atividades do CRD.

Renata usa o termo travestilidade significando orgulho, e constrói esta experiência a partir de convençóes das ciências sociais e militância. Se a travestilidade é um fenômeno e uma experiência identitária, perguntei para Renata o que é ser travesti para ela:

Tem uma definição que gosto muito que as pessoas dão e eu gosto que é colocando a travesti como um terceiro sexo. Não somos homens, não somos mulheres, somos travestis. Somos um terceiro sexo. Eu gosto dessa definição. Mas na minha convicção travesti não seria um terceiro gênero, nem um terceiro sexo. Eu acho que travesti é uma travessia entre gêneros, eu atravesso do masculino para o feminino. E isso dá a maior definição da minha vida que é o buscar, a busca constante, eu me descubro cada vez mais mulher a cada dia que eu acordo. Porque o processo, ao meu entender, é interminável. Eu jamais fui um homem e eu nunca vou ser uma mulher. Eu sempre vou ser essa travessia.

Ela aponta um termo semelhante ao de Bárbara, terceiro sexo. No entanto, destaca ressalvas, pois argumenta que travesti talvez náo seja um terceiro sexo ou gênero, pois é uma travessia. Renata marca aqui uma fluidez do que é travesti. Um tipo de devir constante, uma busca. No entanto, quando ela narra as diferenças entre travestis, transexuais e cross-dressers algumas convenções do que é ser travesti ficam mais evidentes:

A diferença básica entre as CDs, as travestis e as transexuais é que as travestis, embora busquem uma identidade feminina, não reivindicam uma subjetividade feminina como no caso das transexuais. As transexuais buscam o corpo feminino e a subjetividade feminina. Nós não, nós sabemos que não somos mulheres. Nós sabemos que somos travestis. A transexual então não seria um terceiro gênero, ela seria o gênero feminino. A transexual resgata uma identidade retirada da sociedade. A gente não, a gente constrói uma identidade. Nós estamos construindo uma identidade feminina, que a gente não tinha antes. A transexual na verdade resgata uma identidade que foi abafada pela genitália masculina. Eu não tenho nenhum problema com a minha genitália, minha genitália é minha história. Eu considero que o processo da transexual fisicamente é muito mais delicado que o nosso. Em contraposição, o nosso processo socialmente é muito mais complicado. Porque o estigma nosso é muito maior. Travesti é sempre sinônimo de puta, vagabunda e sem vergonha. Transexual é sinônimo de doente. Se eu chegar em um hotel e falar que eu sou transexual é uma outra realidade, se eu falar que eu sou travesti, o gerente do hotel já vai achar que eu vou fazer programa, e já vai dizer que não tem vaga no hotel

Aqui o que vem marcar a diferença entre travestis e transexuais é a cirurgia de transgenitalização. A transexual resgata uma identidade feminina abafada pela genitália. Ela busca uma identidade da sociedade, a identidade mulher com vagina. Lembremos que ser travesti demanda afastar-se dos valores pequeno-burgueses, das identidades da sociedade. O fato de a transexual querer ter uma vagina significa que ela 
quer ser mulher, enquanto as travestis aceitariam sua genitália, sua história, e construiriam uma identidade que não existe na sociedade, uma identidade feminina com pênis.

Estar fora da sociedade significa em seu argumento ter que construir algo novo. $\mathrm{O}$ interessante desta fala é que as travestis de uma posiçáo hierarquicamente inferior, devido a serem ligadas a putas e vagabundas, podem se tornar um exemplo de luta e, nesse sentido, podem se tornar moralmente superiores, já que transexuais reproduziriam as normas da sociedade, enquanto travestis construiriam algo novo. Assim, travestis sáo quem tem que conviver com a marginalidade, preconceito e violência, pois travest $i$ é sinônimo de puta, vagabunda e sem vergonha. Transexuais são doentes, transexuais não aceitam o passado, querem escondê-lo, são infelizes. As características clínicas clássicas da transexualidade são elencadas aqui. Além disso, transexuais têm uma aceitação da sociedade, com a qual as travestis não contam. Ainda segundo Renata:

A travesti acaba sendo a experiência da calçada, da rua, da puta, e a transexual a experiência da Roberta Close, da bonita, da feminina, da doente que vai se tratar no consultório. Transexuais aparecem na mídia como a Roberta Close, imagem positiva da transexual, e no caso das travestis, somente página policial. O senso comum do Brasil associa rapidamente travestis à rua, que tá na prostituição e que possivelmente rouba. Eventualmente tem uma navalha na bolsa. Eu acredito que deve haver um grande número de transexuais, mas que na verdade são travestis, e que se dizem transexuais para escapar do estigma. Uma pessoa que veio da pequena burguesia, que tem posses, que viveu uma vida acostumada às regras sociais e morais, será difícil ela se transformar em uma travesti, ela vai virar transexual, ou vai arranjar um jeito e ser CD ou transformista. Eu sou um caso raro disso, que vim da pequena burguesia e sou travesti. Que bate no peito e diz dá licença, eu sou travesti. Ainda que eu não vá fazer programa eu sou travesti.

Renata aponta que para a sociedade existem exemplos positivos de pessoas transexuais, como Roberta Close, enquanto no caso de travestis somente página policial. Segundo Renata, as travestis, de acordo com o senso comum, são diretamente associadas à prostituição, à rua, ao roubo, à violência e promiscuidade. Assim, uma pessoa que veio da pequena burguesia, que seriam classes médias e altas, se diria transexual para escapar do estigma, mesmo que não seja "realmente" transexual, isto é, tomando as categorias médicas. Renata reafirma as convençóes médicas que estabelecem as diferenças entre travestis e transexuais e as articula com elementos de classe. Ao procurarem transformaçóes de gênero, pessoas da pequena burguesia aspirariam a uma identidade da sociedade, que remete a um corpo, isto é, mulher com vagina, que na narrativa de Renata está ligado às transexuais, e não uma identidade marginal como a travesti, que também remete a um corpo, feminina com pênis. Sociedade, em sua narrativa, é o contrário de marginalidade. Tal relação de classe Renata também aponta em relação às cross-dressers, como no seguinte trecho de sua narrativa:

Mas eu defendo a tese que CDs são travestis. Eu acho que as CDs são um clube criado dentro da pequena burguesia, por travestis estabilizadas financeiramente, de boa carreira profissional, de boas famílias, que não quiseram sofrer a estigmatização de ser travesti. Eu quis ir para uma coisa mais intensa, mais verdadeira.

No argumento de Renata existem duas categorias possíveis para descrever práticas de transformações de gênero: travestis e transexuais. Renata relata assim que $C D$ s são travestis. São pessoas que não querem se desligar de seu status, de seus valores pequeno-burgueses. Elas 
não querem viver a estigmatização de ser travesti; assim, montam um clube no sábado para viver as suas travestilidades. Assumir-se travesti aparece como uma experiência mais verdadeira e intensa que se dizer cross-dresser, que seria uma "mentira" contada para fugir da marginalidade.

\section{Conexóes, posiçóes e diferenças}

Nas narrativas apresentadas sinalizei como os usos de categorias têm relação direta com suas situaçóes presentes. São tais situaçóes e contextos atuais que organizam uma série de eventos em suas trajetórias biográficas. $\mathrm{O}$ acesso à informação e saberes, desde o científico até a internet, permite-lhes se olharem de outra forma. Carla, Bárbara e Renata estão imersas em uma rede de discursos produzidos sobre as pessoas transexuais e travestis, rede esta na qual o próprio discurso antropológico se faz presente, como nos mostra Renata. Categorias e convençôes produzidas pela medicina, militância e academia são rapidamente absorvidas por essas pessoas, que neste processo transformam e deslocam sentidos.

Nesta busca de (re)conhecimento de si foi possível perceber valorizaçóes e tensôes em relação ao saber médico-psiquiátrico. Esta questão fica evidenciada em relação à convenção de que a diferença entre travestis e transexuais seria a cirurgia de transgenitalização, continuamente questionada nas narrativas de Carla e Bárbara. Mesmo que elas coloquem em evidência as concepçóes médicas acerca da diferença entre travestis e transexuais - consideradas "corretas" -, deslocam essas diferenças.

$\mathrm{Na}$ narrativa de Carla as tensões em relação ao saber médico ganham destaque, pois ao mesmo tempo em que ela argumenta em favor da importância e valorização desse saber por seu status de verdade absoluta, ela também aponta conflitos em relação ao controle desse saber sobre seu corpo. Já Bárbara questiona as diferenças entre travestis e transexuais, embora o fato de a categoria transexual ter essa íntima relação com o campo médico faça com que ela prefira hoje se dizer trans, pois procura evocar sentidos ligados à categoria transexual. A categoria trans e transexual evocaria uma imagem de verdadeira mulher em contraposição à categoria travesti, que seria ligada à prostituição e marginalidade, o que, por sua vez, evocaria aspectos masculinos e a homossexualidade.

Diferentemente de Carla e Bárbara, Renata procura afirmar as diferenças entre travestis e transexuais. Em sua narrativa, a afirmação da diferença enquanto positividade por meio da retórica do orgulho travesti evidencia a convenção da cirurgia como a linha que separa travestis e transexuais, além de reiterar essa taxonomia que estipula somente tais categorias como as únicas possíveis para pessoas que praticam transformaçóes de gênero, evidente em sua teoria de que cross-dressers são travestis. Desta forma, o uso do termo travestilidade lhe permite construir esse lugar de orgulho e positividade ao mesmo tempo em que reafirma características clássicas do diagnóstico médico de travestis e transexuais.

Essas questôes sobre as disputas e tensóes entre as categorias travesti e transexual são apontadas por vários outros autores. Leite Jr. (2009) argumenta que quando a categoria transexual começou a ser noticiada nas mídias e na própria medicina no final dos anos 1970 no Brasil foi necessário que houvesse um processo de diferenciação dessa categoria das categorias travesti e homossexual. Segundo o autor, a distinção entre travestis e transexuais tornou-se acentuada no Brasil, pois o termo travesti no Brasil possui décadas de associação com a prostituição e com um imaginário de desregramento sexual e moral.

Desta forma, Leite Jr. argumenta que esse processo de especificação e diferenciação entre travestis e transexuais expressa, menos do que somente um esforço de distinção conceitual, uma diferenciação sociomoral. Leite Jr. ainda destaca o capital simbólico envolvido no uso 
da categoria transexual, por sua ligação com o discurso médico-psiquiátrico, questão reiterada nas narrativas apresentadas:

Como o discurso sobre a transexualidade possui uma aura mais higiênica, forjado nos laboratórios e consultórios da Europa e dos Estados Unidos e ainda pouco disseminado popularmente em suas especificidades teóricas, pode-se afirmar que o termo transexual possui um capital linguístico mais valorizado que o termo travesti, podendo ser mais facilmente convertido em capital social e, desta forma, sendo capaz de abrir ou fechar portas segundo a maneira como a pessoa se autoidentifica ou é identificada. (Leite Jr., 2009, p.221)

Essa busca de distintividade entre travestis e transexuais é algo também notado por Teixeira (2009) em sua análise dos laudos produzidos pelas equipes de médicos e psicólogos que acompanham as candidatas à cirurgia de transgenitalização. A autora salientou como os pareceristas médicos que realizam esses laudos têm uma preocupação especial em descobrir as falsas transexuais, o que mantém as candidatas à cirurgia sob constante tensão e medo. Teixeira reproduz a fala de uma candidata à cirurgia que não conseguiu obter parecer médico favorável e que evidencia sentidos atribuídos à categoria transexual e travesti:

Acabou, você foi reprovada. Você não é transexual. Neste momento eu me senti destruída, ele pegou todos os anos que eu me acreditei mulher e jogou no lixo. Era como se o Estado estivesse me dizendo: você náo é mulher, olha, você é um traveco safado. Era o Estado legitimando tudo que a sociedade pensa de mim: você é um homem vestido de mulher. (Teixeira, 2009, p. 215; grifos meus)

Ligar travestis ao masculino, um feminino mal-sucedido ou fracassado e a ambivalências morais como safadeza parece ser central na produção da distintividade das transexuais, especialmente se considerarmos a perspectiva das que buscam a cirurgia de transgenitalização. Como sinaliza também o trabalho de Bento (2008), muitas pessoas autoidentificadas transexuais procuram se distinguir das travestis ligando estas a um feminino vulgar e exagerado.

Percebemos, portanto, que as categorias travesti e transexual articulam variadas convenções sociais, como convençôes de classe, raça, gênero, sexualidade e geração, produzindo "lugares sociais" no entrelaçamento dessas diversas convenções. Essas categorias se constituem enquanto posições de sujeito nessa articulação (McClintock, 1995).

Embora esses lugares possuam códigos prescritivos, algumas pessoas conseguem transitar entre essas posiçóes. Carla sinaliza em sua narrativa um trânsito entre diversas categorias. Ela disse que utilizava a categoria transexual até pouco tempo, embora não desejasse a cirurgia de transgenitalização, pois não se via como travesti. Bárbara atualmente utiliza o termo trans em algumas situaçôes, a categoria travesti (pois afirma que seria vista como travesti, já que não deseja a cirurgia de transgenitalização) e a categoria homossexual para se referir a suas práticas sexuais. $\mathrm{O}$ uso situacional dessas categorias na narrativa de Bárbara e Carla sinaliza que a efetividade das enunciaçôes dessas categorias depende das situaçôes em que são acionadas, nas quais, embora a cirurgia de transgenitalizaçáo tenha um valor central na demarcação das diferenças, outras convenções de classe, geração, gênero e sexualidade podem compor essa produção e possuir até mesmo maior relevância no processo.

\section{Subjects, Conventions and Differences in Narratives: on Carla, Bárbara and Renata}

abstract This article discusses, based on narratives of life history, the uses of the categories related to 
sexual and gender identities, especially the categories transvestite and transsexual, as well as how the differences between these categories are elaborated. It argues that, although the conventions of medical discourse are central references for the definition of the bodies, subjectivities, and identities of the people investigated, it is possible to notice a variety of re-elaborations and displacement of meanings in the construction of biographical trajectories that is directly related to present social situations and the various contexts of dialogue.

keywords Transvestite. Transsexual. Differences. Gender. Sexuality.

\section{Notas}

1. Utilizarei itálico para me referir a categorias e conceitos êmicos.

2. Pessoas trans é a categoria utilizada pelas participantes das Terças Trans para designar em conjunto travestis, transexuais e outras pessoas que praticam transformaçôes de gênero e utilizam outras categorias, como os homens trans (pessoas designadas como mulheres ao nascer e que se constroem naquilo que consideram masculino) e cross-dressers.

3. Segundo Herzfeld (2005), a poética social refere-se a um conceito que propóe lidar com a ambiguidade permanente da linguagem usada, embora possa servir para o entendimento de todos os tipos de expressáo simbólica. É o foco nas técnicas (retórica) envolvidas na prática social e na contínua imprevisibilidade que os sentidos podem assumir.

4. Literalismo remete à formulação de Crapanzano (2002) sobre diferentes estilos de interpretação, conforme a ênfase atribuída às dimensões presentes nos sistemas de classificação. Para Crapanzano, qualquer sistema de classificação tem pelo menos duas dimensões importantes: uma semântico-referencial e outra pragmática. Tais dimensões não são distintas entre si, mas ele argumenta que é possível perceber, em certos contextos, uma valorização maior de alguma das duas. Dessa perspectiva, o literalismo seria um estilo de interpretação que se caracteriza pelos seguintes aspectos: 1) concentra-se na dimensão referencial ou semântica da linguagem - mais especificamente na palavra -, e não em suas dimensóes pragmáticas; 2) pressupóe uma correlação simples, inequívoca, entre palavra e coisa; 3) insiste no significado único, essen- cial, "ordinário", "habitual”, "de senso comum” da palavra; 4) oferece resistência a qualquer compreensão figurativa, vista como distorcida e até adulterada; 5) frisa a intenção autoral ("intenção original”) como indicadora do significado correto; 6) encara certos textos como fundamentais, como significado básico; 7) dá prioridade ao escrito - o texto - sobre o falado e, no caso de textos sagrados, como a Bíblia, às vezes até sobre a experiência (Crapanzano, 2002, p. 453).

5. Aqui Carla remete às convençôes médicas das diferenças entre travestis e transexuais. Essas convençốes encontram-se sintetizadas em Manuais Internacionais utilizados por médicos e psicólogos, como o CID 10 (Classificação Estatística Internacional de Doenças e Problemas Relacionados com a Saúde) e o DSM IV (Manual Diagnóstico e Estatístico de Doenças Mentais) e continuam semelhantes às definiçôes de Harry Benjamin, autor que sistematizou o conceito de transexualismo na década de 1950. Para o autor, as diferenças básicas entre travestis e transexuais encontram-se na relaçáo que cada qual mantém com seu respectivo órgão genital e com o desejo da cirurgia de transgenitalização: enquanto as travestis não desejam esta cirurgia e sentem prazer com o órgão genital, as transexuais a desejam e sentem desconforto e "profunda infelicidade” em relaçấo ao seu órgão genital. Para o autor, isso estaria associado ao desenvolvimento de convicções distintas de identidade de gênero; assim, as travestis não se sentem mulheres, sabem que são homens, enquanto as transexuais afirmam que sempre se sentiram mulheres, desde o nascimento.

6. O conceito é cunhado por Anderson (2005) em sua análise sobre "naçáo", embora possa ser estendido a outros tipos de "comunidades" baseadas no compartilhamento de certas experiências, sendo uma forma de crítica à noção de grupo. Para o autor a comunidade é "imaginada", pois mesmo no menor dos países seus cidadãos não se conhecem e, mesmo assim, compartilham a ideia de que fazem parte do mesmo "grupo" e que, deste modo, compartilham certas experiências comuns.

7. Dentre os trabalhos das ciências sociais citados por Renata encontram-se Benedetti (2005), Bento (2008) e Pelúcio (2007).

\section{Referências bibiográficas}

ANDERSON, Benedict. Comunidades Imaginadas: Reflexōes Sobre a Origem e a Expansão do Nacionalismo. Lisboa: Edições, 2005.

cadernos de campo, São Paulo, n. 19, p. 47-68, 2010 
68 | Bruno Cesar Barbosa

BARBOSA, Bruno Cesar. Nomes e Diferenças: uma entnografia dos usos das categorias travesti e transexual. Dissertação (mestrado). Faculdade de Filosofia, Letras e Ciências Humanas, Universidade de São Paulo, São Paulo, 2010.

BENEDETTI, Marcos. Toda Feita: corpo e o gênero das travestis. Rio de Janeiro: Garamond, 2005.

BENTO, Berenice. O que é transexualidade? Sáo Paulo, Brasiliense, 2008.

BOURDIEU, Pierre. A ilusão biográfica. In: FERREIRA, Marieta M.; AMADO, Janaína (Orgs.). Usos e abusos da história oral. Rio de Janeiro: Editora FGV, 1996. p. 183-191.

BUTLER, Judith. Problemas de gênero: feminismo e subversão da identidade. Rio de Janeiro: Civilização Brasileira, 2003.

BRAH, Avtar. Diferença, diversidade, diferenciação. Cadernos Pagu (26). janeiro-junho de 2006, pp.329376.

CARROLL, Lewis. Alice no Pais das Maravilhas. Porto Alegre: L\&PM Pocket, 2007 [1895].

CRAPANZANO, Vincent. Estilos de interpretação e a retórica das categorias sociais. In: MAGGIE, Y.;REZENDO, C. (Org.). Raça como Retórica: a construção social da diferença. Rio de Janeiro: Civilização Brasileira, 2002.

FACCHINI, Regina. Entre umas e outras: Mulheres, (homo)sexualidades e diferenças na cidade de São Paulo.
Tese (doutorado). Instituto de Filosofia, Letras e Ciências Humanas, Universidade Estadual de Campinas, Campinas, 2008.

HERZFELD, Michael. Intimidade cultural: Poética social no Estado-Naçâo. Coimbra: Edições 70, 2005.

KOFES, Suely. Experiências Sociais, Interpretaçôes Individuais: histórias de vida, suas possibilidades e limites. In: Cadernos Pagu (3), 1994, pp.117-141.

LEITE JÚNIOR, Jorge. "Nossos Corpos Também Mudam": sexo, gênero e a invençấo das categorias "travesti" e "transexual" no discurso médico científico. Tese (doutorado). Pontifícia Universidade Católica. São Paulo, 2008.

MCCLINTOCK, Anne. Imperial Leather: Race, Gender, and Sexuality in the Colonial Context. Nova York: Routledge, 1995.

PELUCIO, Larissa Maués. Nos nervos, na carne e na pele - Uma etnografia sobre prostituição travesti e o modelo preventivo de aids. Tese (doutorado). Universidade Federal de São Carlos, São Carlos, 2007.

TEIXEIRA, Flávia do Bonsucesso. Vidas que desafiam corpos e sonhos: uma etnografia do construir-se outro no gênero e na sexualidade. Tese (doutorado). Instituto de Filosofia e Ciências Humanas, Universidade Estadual de Campinas, Campinas, 2009.

WAGNER, Roy. The Invention of Culture. Chicago: Chicago University Press, 1981.

autor Bruno Cesar Barbosa

Doutorando em Antropologia Social / USP

Recebido em 07/03/2010

Aceito para publicação em 20/09/2010

cadernos de campo, São Paulo, n. 19, p. 47-68, 2010 